\title{
Effect of Organic Manure and Sulfur Application on Maize (Zea mays L.)
}

\author{
Darwish, H. A. \\ Maize Research Program, Field Crops Res. Inst., A.R.C., EGYPT
}

\begin{abstract}
A field experiment was performed in Gemmiza Agricultural Research Station in 2013 and 2014 seasons and Nubaria Agricultural Research Stations in 2014 season to study the effect of manure and sulfur applications on maize grain yield and other traits. The results showed that the differences due to manure application significantly affected grain yield, plant height and kernels weight. The effect of manure application significantly increased grain yield, where both 10 and $20 \mathrm{~m}^{3}$ of manure treatments gave the highest grain yield at Gemmiza in 2013 season (30.2, $30.5 \mathrm{ardab} / \mathrm{fed}$.), and Nubaria in 2014 season, (31.1 and $33.3 \mathrm{ardab} / \mathrm{fed}$ ), respectively. Manure application significantly affected on kernels weight, where $20 \mathrm{~m}^{3}$ manure treatment gave the highest value of 100 -kernel weight $(39.7 \mathrm{~g})$ followed by $10 \mathrm{~m} 3$ manure $(37.1$ g) at Gemmiza in 2013 season. It was noticed that $20 \mathrm{~m}^{3}$ manure treatment gave the highest value of ear length. The application of 10 and $20 \mathrm{~m}^{3}$ manure gave significantly the tallest plants. Significant differences were detected among sulfur application for grain yield. Sulfur application of $200 \mathrm{~kg} / \mathrm{fed}$ gave more significant means of grain yield. Mean grain yield at Gemmiza in 2013 season for $200 \mathrm{~kg} / \mathrm{fed}$ sulfur was $32.2 \mathrm{ard} / \mathrm{fed}$ compared with $28.5 \mathrm{ard} / \mathrm{fad}$ for $100 \mathrm{~kg} / \mathrm{fed}$ sulfur treatment. At 2014 season, $200 \mathrm{~kg} / \mathrm{fed}$ sulfur treatment gave 26.2 and $33.6 \mathrm{ard} / \mathrm{fed}$ at Gemmiza and Nubaria, respectively. Sulfur application of $200 \mathrm{~kg} / \mathrm{fed}$ increase ear length with values of $22.2 \mathrm{~cm}$ compared with 21.2 and $21.7 \mathrm{~cm}$ for the other treatments $(100 \mathrm{~kg} / \mathrm{fed}$ and non sulfur) at Nubaria in 2014 season. Treatment of $200 \mathrm{~kg}$ sulfur had the tallest plants in 2014 season with values of 225.0 and $220.2 \mathrm{~cm}$ at Gemmiza and Nubaria, respectively. Manure-by-sulfur interaction significantly affected 100-kernel weight at Gemmiza location in 2013 and 2014 seasons, ear length and ear height at Nubaria location in 2014 season. Generally, manure and sulfur application increased 100-kernel weight at 2013 and 2014 seasons. Also, $20 \mathrm{~m}^{3}$ manure with $200 \mathrm{~kg}$ sulfur treatment gave significantly the highest value of ear length at Nubaria region in 2014 season $(22.7 \mathrm{~g})$.
\end{abstract}

Keywords: Zea mays, Maize, Organic manure, Sulphur, Nubaria, Gemmiza.

\section{INTRODUCTION}

Continuous use of fertilizers creates potential polluting effect in the environment (Oad et al., 2004). Synthesis of chemical fertilizers consumes a large amount of energy and money. However, an organic farming seems to be possible solution for these situations (Prabu et al., 2003). Farming practices which involve heavy application of chemical fertilizers may cause depletion of certain nutrients in soil and certain others would generally accumulate in excess resulting in nutrient imbalance which affects the soil productivity. Some of these problems can be tackled by using bio-fertilizers, which are natural, beneficial and ecologically friendly. In agricultural production, organic manure and biofertilizer play an important role to possess many desirable soil properties and exerts beneficial effect on the soil physical, chemical and biological characteristics. Manure can substitute for inorganic $\mathrm{N}$ fertilizer and can mitigate potential soil deterioration under irrigated corn (Zea mays L.), (Ardell et al., 2015). Fresh manure decreased corn emergence by $9.5 \%$ compared with the unamended, non fertilized control treatment. Applied manure increased maize grain yield and biomass at tasseling. The application of organic matter as a strategy to boost maize production can be increased up to $140 \%$ relative to treatments without organic matter application (Bernard et al., 2016). These 
relatively low responses to the application of organic matter are related to the low nitrogen recovery by a following crop. The combined application of organic matter and fertilizer can easily lead to 200 to $400 \%$ increases in maize grain yield relative to an unamended control and give absolute yield increases easily exceeding $2000 \mathrm{~kg}_{\text {grain }} \mathrm{ha}^{-1}$.

The importance of sulfur in a fertilizer program for corn has been the focus of diverse research projects conducted over several years at various locations. Sulfur availability indicators are necessary for rational use of sulfur fertilizers (Agustin and Echeverria, 2011).Broadcast application of sulfur in a band near the seed at planting has proven to be satisfactory in most production situations (George and Clapp, 2008). Sulfur application significantly increased grain yield, total biomass, sulfur concentration and nitrogen concentration in total biomass. Sulfur deficiency symptoms are more often observed in crops at early stages of growth since sulfur can be easily leached from the surface soil (Kiyoko, et al., 2005). Significant response to sulfur was shown by maize in all experiments. A response curve for sulfur showed that 5 to $10 \mathrm{~kg} / \mathrm{ha}$ of Sulfur was optimal, with mean yield response ranging from 90 to $142 \mathrm{~kg}$ grain/ $\mathrm{kg}$ sulfur (Ray and Mughogho, 2000). Sulfur application significantly increased grain yield of maize, and also increased total biomass (Agustin and Echeverria, 2011).

This study is carried out to determine the effect of manure and sulphur application on maize grain yield and other traits at two different environments.

\section{MATERIALS AND METHODS}

A field experiment was performed in Gemmiza Agricultural Research Station in 2013 and 2014 seasons and Nubaria Agricultural Research Station in 2014 season to study the effect of organic manure and sulfur applications on maize grain yield and other traits. Organic manure treatments were 10 and 20 $\mathrm{m}^{3} / \mathrm{faddan}$, while the rates of sulfur were 200 and $400 \mathrm{~kg} / \mathrm{faddan}$, in addition to treatment of zero application (control). Manure and sulfur were applied during soil preparation for cultivation at the plowed layer before planting. Maize variety SC.167 was used at this study. Soil samples were collected before planting and analyzed for some physical and chemical properties (Table 1). Also, samples of organic manure were analyzed according to Black (1982) and the most important characteristics are shown in Table (2). Farmyard organic manure was produced at Nubaria and used at both locations. The experimental design was split-plot with four replications. Manure treatments were randomly assigned to the main-plots, while sulfur treatments were randomly assigned to the sub-plots. Sowing date was in the first of June at both locations. Plot size was four rows, 6 $\mathrm{m}$ long and $80 \mathrm{~cm}$ apart and hills were spaced $20 \mathrm{~cm}$ along the row. Data were collected for number of days to mid-silking (silking date), plant and ear heights $(\mathrm{cm})$, ear length (cm), 100-kernels weight $(\mathrm{g})$ and grain yield (ardab/faddan). Ears per plot were weighed and about five $\mathrm{kg} / \mathrm{plot}$ were taken for moisture percent determination. Grain yield was expressed as ardab/faddan ( $\left.\mathrm{ard} / \mathrm{fad}^{-1}\right)$ at $15.5 \%$ moisture content. The obtained data were statistically analyzed according to Steel and Torrie (1980), using SAS software (1997). 
Table (1). Physical and chemical analysis of the field experiment at Gemmiza and Nubaria, during 2014 season.

\begin{tabular}{lcc}
\hline \multicolumn{1}{c}{ Variables } & Nubaria & Gemmiza \\
\hline Clay \% & 22.00 & 45.8 \\
Silt \% & 28.50 & 21.5 \\
Sand \% & 49.50 & 35.1 \\
Texture & Sand clay loam & Clay \\
pH & 8.2 & 8.3 \\
Available N $(\mathrm{mg} / \mathrm{kg})$ & 33.8 & 41.1 \\
Available K $(\mathrm{mg} / \mathrm{kg})$ & 119 & 198.5 \\
Available P $(\mathrm{mg} / \mathrm{kg})$ & 4.97 & 15.5 \\
\hline
\end{tabular}

Table (2). Physical and chemical analysis of organic manure used in this study at Gemmiza and Nubaria.

\begin{tabular}{lcc}
\hline \multicolumn{1}{c}{ Character } & & Value \\
\hline Bulk density & $\mathrm{kg} / \mathrm{m}^{3}$ & 736 \\
Moisture content & $\%$ & 9.6 \\
$\mathrm{pH}$ & & 7.4 \\
EC (1:10 water extract) & $\mathrm{dS} / \mathrm{m}$ & 2.75 \\
Organic matter & $\%$ & 73.78 \\
Organic carbon & $\%$ & 43.40 \\
C/N ratio & $\%$ & 19.91 \\
Total N & $\%$ & 2.18 \\
Total P & $\%$ & 0.47 \\
Total K & $\%$ & 1.24 \\
Available N & $(\mathrm{mg} / \mathrm{kg})$ & 223 \\
Available P & $(\mathrm{mg} / \mathrm{kg})$ & 259 \\
Available K & $(\mathrm{mg} / \mathrm{kg})$ & 860 \\
\hline
\end{tabular}

\section{RESULTS AND DISCUSSION}

\section{Manure effects}

The results in Table (3) showed that the application of manure fertilizer treatments were significantly affected the grain yield and plant height during 2013 and 2014 seasons at Gemmiza and Nubaria region at 2014. Significant differences were observed for ear height and kernels weight at Gemmiza 2013 season, as well as ear length and ear height at Nubaria 2014 season. Application of manure fertilizer increased plant height and grain yield. The positive effect of manure on plant growth might be attributed to its role in improving soil structure through aggregate formation, hydraulic properties and also through providing plants with some of their needs from macro and microelements. These results are in agreements with those obtained by Abou ElMaged et al., (2008), Abd El-Wahed, (2009), Ahmed et al., (2011) and ElMekser et al., (2014). The results in Table (4) showed that the manure application significantly increased grain yield, where both 10 and $20 \mathrm{~m} 3$ of manure treatments gave the highest mean grain yield at Gemmiza in 2013 season and Nubaria in 2014 season compared with non application of manure 
(30.2, 30.5, 31.1 and $33.3 \mathrm{ard} / \mathrm{fad}$, respectively, compared with 25.9 and 28.1 ard/fad. In Gemmiza in 2014 season, 20 m3 manure treatment gave significantly higher at value of grain yield (26.7 ard/fad) compared with the other two treatments (24.5 and $24.7 \mathrm{ard} / \mathrm{fad}$ ). At Gemmiza in 2013 season, manure application had significant affect on kernels weight, where $20 \mathrm{~m}^{3}$ manure treatment gave the highest value of 100 -kernel weight $(39.7 \mathrm{~g})$ followed by 10 $\mathrm{m}^{3}$ manure $(37.1 \mathrm{~g})$ compared with $35.3 \mathrm{~g}$ for no manure added (Table 4). Regarding ear length, at both locations in 2014 season, manure application increased ear length, where $20 \mathrm{~m}^{3}$ manure treatment gave the highest value of ear length $(21.5$ and $22.2 \mathrm{~cm}$ ) compared with the other treatments. Also, the application of 10 and $20 \mathrm{~m}^{3}$ manure to maize plant gave significantly the tallest plants at Gemmiza in 2013 season (238.3 and $236.2 \mathrm{~cm}$ ) compared with 227.9 $\mathrm{cm}$ with non manure added (control treatment), (Table 4). In 2014 season, at both locations, the treatment of $20 \mathrm{~m} 3$ manure gave significantly the tallest plants $(224.6$ and $221.7 \mathrm{~cm}$ ), while, $10 \mathrm{~m} 3$ manure treatment was not significantly different from no application at Gemmiza and Nubaria. At Gemmiza in 2013 season and Nubaria in 2014 season, manure application of 20 m3 gave significantly increased of mean ear height $(139.2$ and $125.7 \mathrm{~cm})$ compared with the other treatments, although 10 and $20 \mathrm{~m} 3$ manure treatments didn't significant differe at Nubaria in 2014 season (124.7 and $125.7 \mathrm{~cm}$ ). Results showed that manure application didn't affect number of days to mid-silking at both locations.

Table (3). Mean square for grain yield and other traits of three manure and three sulfur treatments at Gemmiza during 2013 and 2014 and Nubaria during 2014.

\begin{tabular}{lccccccc}
\hline \multicolumn{1}{c}{ S.O.V. } & df & $\begin{array}{c}\text { Grain } \\
\text { yield }\end{array}$ & $\begin{array}{c}\text { 100- } \\
\text { Kernel } \\
\text { weight }\end{array}$ & $\begin{array}{c}\text { Ear } \\
\text { length }\end{array}$ & $\begin{array}{c}\text { Silking } \\
\text { date }\end{array}$ & $\begin{array}{c}\text { Plant } \\
\text { height }\end{array}$ & $\begin{array}{c}\text { Ear } \\
\text { height }\end{array}$ \\
\hline Gemmiza-2013 \\
\hline Replications(Rep) & 3 & 10.96 & 0.32 & 1.62 & 0.37 & 19.44 & 3.56 \\
Manure (Man) & 2 & $77.45^{* *}$ & $57.03^{* *}$ & 3.73 & 1.03 & $364.58^{*}$ & $136.11^{*}$ \\
Rep x Man & 6 & 0.56 & 2.88 & 1.75 & 0.40 & 36.80 & 16.67 \\
Sulfur (Sul) & 2 & $1118.19^{* *}$ & $15.53^{* *}$ & 0.27 & 0.19 & 14.58 & 21.53 \\
Man x Sul & 4 & 5.82 & $7.48^{* *}$ & 0.54 & 0.07 & 47.92 & 17.36 \\
Error & 18 & 2.85 & 1.61 & 1.12 & 0.33 & 19.21 & 17.82 \\
\hline \multicolumn{7}{c}{ Gemmiza-2014 } \\
\hline Replications(Rep) & 3 & 1.18 & 3.95 & 0.17 & 0.62 & 90.47 & 86.11 \\
Manure (Man) & 2 & $17.48^{*}$ & 9.48 & 2.46 & 0.08 & $118.75^{* *}$ & 71.53 \\
Rep x Man & 6 & 2.15 & 6.82 & 0.53 & 0.23 & 20.60 & 68.75 \\
Sulfur (Sul) & 2 & $12.51^{*}$ & 12.46 & 0.01 & 0.08 & $133.33^{* *}$ & 96.53 \\
Man x Sul & 4 & 0.78 & $35.68^{*}$ & 0.48 & 0.29 & 42.71 & 10.07 \\
Error & 18 & 2.18 & 9.61 & 1.07 & 0.22 & 21.06 & 34.26 \\
\hline & \multicolumn{7}{c}{ Nubaria-2014 } \\
\hline Replications(Rep) & 3 & 10.35 & 12.47 & 0.08 & 0.63 & 21.63 & 5.70 \\
Manure (Man) & 2 & $79.27^{* *}$ & 7.88 & $2.07^{*}$ & 3.69 & $499.53^{*}$ & $93.25^{*}$ \\
Rep x Man & 6 & 7.52 & 5.72 & 0.33 & 1.55 & 87.71 & 9.40 \\
Sulfur (Sul) & 2 & $26.72^{*}$ & $32.47^{*}$ & $2.54^{*}$ & 1.03 & 197.44 & $93.00^{*}$ \\
Man x Sul & 4 & 2.88 & 19.27 & $2.44^{*}$ & 0.94 & 46.36 & $106.75^{* *}$ \\
Error & 18 & 7.47 & 7.41 & 0.47 & 0.60 & 61.13 & 19.16 \\
\hline
\end{tabular}

Vol. 21(4), 2016 


\section{Sulfur effect}

Significant and highly significant differences were detected among sulfur application treatments for grain yield at both seasons in Gemmiza and Nubaria locations (Table 3). Also, plant height was affected by sulfur application at Gemmiza location in 2014 season. Significant differences were observed at Nubaria location on 2014 season for ear height, ear length and 100-kernel weight. Manure-by-sulfur interaction was significant on 100-kernel weight at Gemmiza location in 2014 season, ear height and ear length at Nubaria in 2014 season.

Table (4). Averages of grain yield and other traits for manure and sulfur treatments at Gemmiza during 2013 and 2014 and Nubaria during 2014.

\begin{tabular}{|c|c|c|c|c|c|c|}
\hline Treatment & $\begin{array}{l}\text { GrainYield } \\
\text { (Ardab/fed.) }\end{array}$ & $\begin{array}{c}100- \\
\text { Kernel } \\
\text { weight(g) }\end{array}$ & $\begin{array}{c}\text { Ear } \\
\text { Length } \\
\text { (cm) }\end{array}$ & $\begin{array}{c}\text { Silking } \\
\text { date(day) }\end{array}$ & $\begin{array}{c}\text { Plant } \\
\text { height } \\
\text { (cm) }\end{array}$ & $\begin{array}{c}\text { Ear } \\
\text { Height } \\
\text { (cm) }\end{array}$ \\
\hline \multicolumn{7}{|c|}{ Gemmiza-2013 } \\
\hline \multicolumn{7}{|c|}{ Manure (m 3 /fed.) } \\
\hline 0 & $25.9 b$ & $35.3 c$ & 20.8 & 60.2 & $227.9 b$ & 133.3b \\
\hline 10 & $30.2 a$ & $37.1 b$ & 21.6 & 60.5 & $238.3 a$ & $133.3 b$ \\
\hline 20 & $30.5 a$ & $39.7 a$ & 21.8 & 59.9 & $236.2 a$ & $139.2 a$ \\
\hline LSD $_{0.05}$ & 0.7 & 1.7 & Ns & Ns & 6.0 & 4.1 \\
\hline \multicolumn{7}{|c|}{ Sulfur (kg/fed.) } \\
\hline 0 & $25.9 c$ & $36.3 b$ & 21.3 & 60.1 & 233.3 & 133.7 \\
\hline 100 & $28.5 b$ & $37.2 \mathrm{~b}$ & 21.6 & 60.2 & 233.7 & 136.2 \\
\hline 200 & $32.2 a$ & $38.6 a$ & 21.4 & 60.3 & 235.4 & 135.8 \\
\hline LSD $_{0.05}$ & 1.4 & 1.1 & Ns & Ns & Ns & ns \\
\hline \multicolumn{7}{|c|}{ Gemmiza-2014 } \\
\hline \multicolumn{7}{|c|}{ Manure (m³/fed.) } \\
\hline 0 & $24.5 b$ & 42.0 & $20.6 b$ & 62.3 & $218.3 b$ & 137.1 \\
\hline 10 & $24.7 \mathrm{~b}$ & 43.4 & $21.0 a b$ & 62.4 & $221.1 \mathrm{ab}$ & 136.3 \\
\hline 20 & $26.7 a$ & 43.7 & $21.5 a$ & 62.5 & $224.6 a$ & 140.8 \\
\hline $\mathbf{L S D}_{0.05}$ & 1.5 & Ns & 0.7 & Ns & 4.5 & ns \\
\hline \multicolumn{7}{|c|}{ Sulfur (kg/fed.) } \\
\hline 0 & $24.2 b$ & 42.5 & 21.1 & 62.4 & $218.3 b$ & $135.8 b$ \\
\hline 100 & $25.5 a$ & 42.3 & 21.0 & 62.5 & $221.7 a b$ & $137.1 \mathrm{ab}$ \\
\hline 200 & $26.2 a$ & 44.2 & 21.1 & 62.3 & $225.0 a$ & $141.3 a$ \\
\hline LSD $_{0.05}$ & 1.2 & Ns & Ns & Ns & 3.9 & 5.0 \\
\hline \multicolumn{7}{|c|}{ Nubaria-2014 } \\
\hline \multicolumn{7}{|c|}{ Manure (m³/fed.) } \\
\hline 0 & $28.1 \mathrm{~b}$ & 34.6 & $21.4 b$ & 62.1 & $209.3 b$ & $120.5 b$ \\
\hline 10 & $31.1 \mathrm{a}$ & 37.1 & $21.5 b$ & 62.0 & 218.6ab & $124.7 \mathrm{a}$ \\
\hline 20 & $33.3 a$ & 38.1 & $22.2 a$ & 61.1 & $221.7 \mathrm{a}$ & $125.7 a$ \\
\hline $\mathbf{L S D}_{0.05}$ & 2.7 & Ns & 0.6 & Ns & 9.3 & 3.1 \\
\hline \multicolumn{7}{|c|}{ Sulfur (kg/fed) } \\
\hline 0 & $28.2 b$ & $35.5 b$ & $21.2 \mathrm{~b}$ & 61.7 & $212.2 b$ & $121.2 \mathrm{~b}$ \\
\hline 100 & $30.8 a b$ & $37.5 \mathrm{ab}$ & $21.7 \mathrm{~b}$ & 62.0 & 217.3ab & $123.1 \mathrm{ab}$ \\
\hline 200 & $33.6 \mathrm{a}$ & $38.7 a$ & $22.2 a$ & 61.4 & $220.2 a$ & $126.7 a$ \\
\hline $\mathrm{LSD}_{0.05}$ & 4.1 & 2.3 & 0.6 & Ns & 6.7 & 3.7 \\
\hline
\end{tabular}


Results in Table (4) showed that sulfur application of $200 \mathrm{~kg} / \mathrm{fad}$ gave more significant means of grain yield than the other treatments at Gemmiza and Nubaria in 2013 and 2014 seasons. Mean grain yield at Gemmiza in 2013 season of $200 \mathrm{~kg} / \mathrm{fed}$ sulfur was $32.2 \mathrm{ard} / \mathrm{fad}$ compared with $28.5 \mathrm{ardab} / \mathrm{fed}$ for $100 \mathrm{~kg} / \mathrm{fed}$ sulfur treatments which were significantly higher than no application of sulfur (25.9 ard/fed). In 2014 season, $200 \mathrm{~kg} / \mathrm{fed}$ sulfur treatment gave 26.2 and $33.6 \mathrm{ard} / \mathrm{fed}$ at Gemmiza and Nubaria, respectively, which was not significantly different from $100 \mathrm{~kg} / \mathrm{fad}$ sulfur treatment $(25.5$ and $30.8 \mathrm{ardab} / \mathrm{fed})$ at Gemmiza and Nubaria, respectively.

Also, $200 \mathrm{~kg}$ sulfur application had significantly heavier 100-kernel weight mean than the other treatments at Gemmiza in 2013 and Nubaria in 2014 seasons (38.6 and $38.7 \mathrm{~g}$ ), while the treatment of $100 \mathrm{~kg}$ sulfur didn't significantly differe from no application of sulfur (Table 4). Sulfur application of $200 \mathrm{~kg} / \mathrm{fad}$ increase ear length with values of $22.2 \mathrm{~cm}$ compared with 21.2 and $21.7 \mathrm{~cm}$ under the other treatments (100 kg/fad and no sulfur) at Nubaria in 2014 season (Table 4). The same trend was observed for plant and ear heights due to sulfur application at Gemmiza and Nubaria in 2013 and 2014 seasons. Treatment of $200 \mathrm{~kg}$ sulfur gave the tallest plants in 2014 season with values of 225.0 and $220.2 \mathrm{~cm}$ at Gemmiza and Nubaria, respectively. Also, higher values of ear height were detected due to $200 \mathrm{~kg}$ sulfur in 2014 season with values of 141.3 and $126.7 \mathrm{~cm}$ at Gemmiza and Nubaria, respectively (Table 4). As shown in Table (3), It was noticed that sulfur application didn't affect number of days to mid-silking date at both tested locations, Gemmiza and Nubaria in 2013 and 2014 seasons.

Significant response of maize to sulfur was shown in all experiments. A response curve for sulfur showed that 5 to $10 \mathrm{~kg} / \mathrm{ha}$ of Sulfur was optimal, with mean yield response ranging from 90 to $142 \mathrm{~kg}$ grain/kg sulfur (Ray and Mughogho, 2000). Sulfur application significantly increased grain yield of maize, and also increased total biomass (Agustin and Echeverria, 2011).

Manure-by-sulfur interaction significantly affected 100-kernel weight at Gemmiza location in 2013 and 2014 seasons, ear length and ear height at Nubaria location in 2014 season. Generally, manure and sulfur application increase 100-kernel weight in both seasons. Treatment of $20 \mathrm{~m}^{3}$ of manure and $200 \mathrm{~kg}$ sulfur significantly increased 100-kernel weight more than the other treatments in both seasons, and gave values of 100-kernel weight of about 40.7 and $45.8 \mathrm{~g}$ in 2013 and 2014 seasons, respectively (Table 5), while the other treatments gave significantly the lowest values of 100 -kernel weight. Also, $20 \mathrm{~m}^{3}$ manure with $200 \mathrm{~kg}$ sulfur treatment gave significantly the highest value of ear length at Nubaria $(22.7 \mathrm{~g})$ as compared with the other treatments (Table 5). Treatment of $20 \mathrm{~m} 3$ manure with $200 \mathrm{~kg}$ sulfur gave significantly the highest mean of ear height at Nubaria $(134.2 \mathrm{~cm})$ as compared with the other treatments (Table 5). 
Table (5). Effect of interaction between manure and sulfur application on some traits at Gemmiza during 2013 and 2014 and Nubaria during 2014.

\begin{tabular}{cccccc}
\hline \multirow{2}{*}{ Treatment } & \multicolumn{2}{c}{$\begin{array}{c}\text { 100-kernel } \\
\text { weight } \mathbf{( g )}\end{array}$} & $\begin{array}{c}\text { Ear } \\
\text { length } \\
\text { (cm) }\end{array}$ & $\begin{array}{c}\text { Ear } \\
\text { height } \\
\text { (cm) }\end{array}$ \\
\cline { 3 - 6 } & & \multicolumn{2}{c}{ Gemmiza } & Nubaria & Nubaria \\
\hline $\begin{array}{c}\text { Manure } \\
\text { (m } \mathbf{3} / \text { fed.) }\end{array}$ & $\begin{array}{c}\text { Sulfur } \\
\text { (kg/fed.) }\end{array}$ & $\mathbf{2 0 1 3}$ & $\mathbf{2 0 1 4}$ & $\mathbf{2 0 1 4}$ & $\mathbf{2 0 1 4}$ \\
\hline 0 & 0 & 32.7 & 42.6 & 21.1 & 116.2 \\
& 100 & 36.0 & 40.8 & 21.1 & 121.2 \\
& 200 & 37.2 & 42.6 & 22.1 & 124.0 \\
10 & 0 & 36.2 & 39.1 & 20.3 & 121.7 \\
& 100 & 37.2 & 43.9 & 21.6 & 126.2 \\
& 200 & 37.7 & 47.1 & 22.5 & 126.2 \\
& 0 & 38.2 & 42.3 & 21.6 & 121.0 \\
& 100 & 40.0 & 42.8 & 22.1 & 122.0 \\
& 200 & 40.7 & 45.8 & 22.7 & 134.2 \\
\hline LSD $_{\mathbf{0 . 0 5}}$ & & $\mathbf{0 . 6}$ & $\mathbf{1 . 5}$ & $\mathbf{0 . 3}$ & $\mathbf{2 . 1}$ \\
\hline
\end{tabular}

\section{REFERENCES}

Abd El-Wahed,M.H. (2009). Effect of irrigation scheduling and organic manure on barley yield, yield components and water use efficiency under arid regions conditions. Egypt J. Of Appl. Sci., 24(5b):856-877.

Abou El-Magd,M.M.; M.F.Zaki and S.D.Abou-Hussein. (2008). Effect of organic manure and different levels of saline irrigation water on growth, grain yield and chemical content of sweet fennel. Aust. J. Basic \& Appl. Sci., 2:90-98.

Agustin, P. and H.E.Echeverria. (2011). Performance of sulphur diagnostic methods for corn. American Society of Agronomy. Digital Library.

Ahmad,S.Y., E.A.Ali and M.H.Abd El-Wahed. (2011). Some physiological and agronomical traits of corn and water use efficiency as affected by irrigation scheduling and farmyard manure mulching under drip irrigation system. Egypt j. Appl. Sci., 26(1):1-16.

Ardell D.H., C.E.Stewart and S.J.D.Grosso. (2015). Manure and inorganic nitrogen affect irrigated corn yields and soil properties. American Society of Agronomy, (1):215-220.

Bernard, V., J. Wendt and J. Diels. (2016). Combined application of organic matter and fertilizer. American Society of Agronomy. Book: "Sustaining Soil Fertility in West Africa".

Black,C.A. (1982). Methods of Soil Analysis. Amer. Soc. Agron. Inc. Madison Wiscon., USA.

El-Mekser,H.Kh.A.; M.M.M.Hassan and H.A.A.Darwish. (2014). Effect of organic and mineral fertilization on growth and yield of maize. Egypt J. Of Appl. Sci., 29(12)669-681.

George W.R and J.G.Clapp. (2008). Sulfur in a fertilizer program for corn. American Society of Agronomy, (1)143-152. 
Kiyoko, H.; M.Yamada and D. Klepker. (2005). Sulfur requirement of eight crops at early stages of growth. American Society of Agronomy, (1) 95101.

Oad,F.C., U.A.Buriro and S.K.Agha. (2004). Effect of organic and inorganic fertilizer application on maize fodder production. Asian J. Plant Sci., 3(3):375-377.

Prabu,T., P.R.Narwadkar; A.K.Sanindranath and M.Rafi.(2003). Effect of integrated nutrient management on growth and yield of okra cv. Parbhani Kranti. Orissa J. Hort., 31(1):17-21.

Ray R.W. and S.K.Mughogho. (2000). Sulfur nutrition of maize in four regions of Malawi. Agronomy Journal, (4) 1908-1912.

SAS Software. (1997). SAS/STAT software. Release 6.12. SAS Inst. Cary, NC., USA.

Steel,R.G.D. and J.H.Torrie. (1980). "Principles and Procedures of Statistics": A Biometrical Approach. $2^{\text {nd }}(\mathrm{ed})$. Mc Graw-Hill Book Co., New York, USA.

الملخص العربى

تأثير اضافه السماد العضوى والكبريت على الذره الشاميه

هاني عبدالعاطي درويش

برنامج بحوث الذرة الثامية - معهد بحوث المحاصيل الحقلية - مركز البحوث الزراعية - مصر

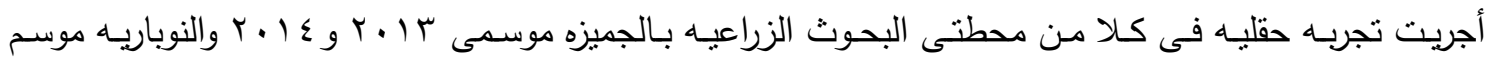

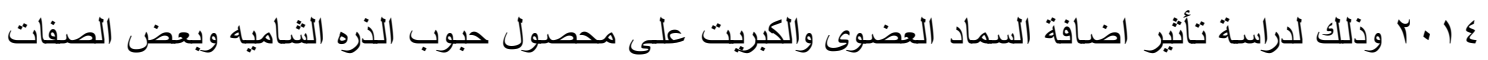

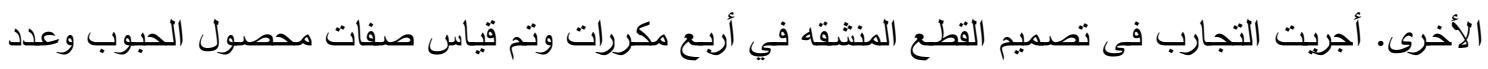

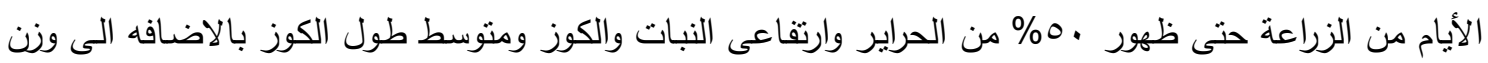

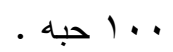

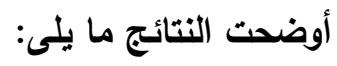
- وجود فروق معنوية راجعه الى اضـافة السماد العضوى لصفتى محصول الحبوب وارتفاع النبات ووزن . . 1.

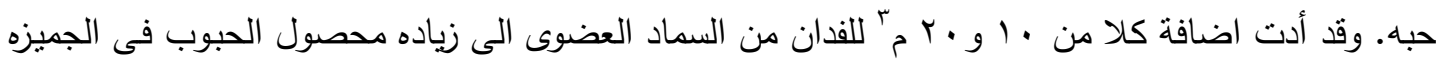

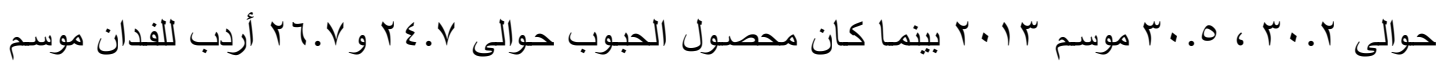

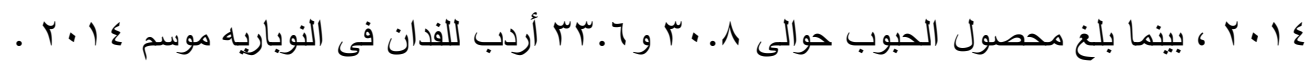

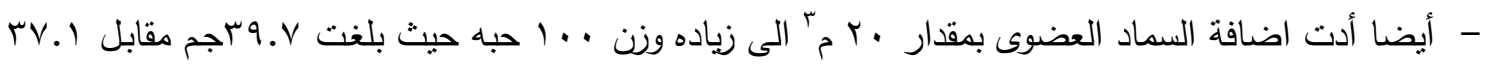
جم لاضافة • ارمّ من الماده العضويه للفدان. - أدت اضافة السماد العضوى الى زياده معنويه فى ارتفاع النبات وطول الكوز • - كما تلاحظ وجود فروق معنويه فى محصول الحبوب راجعه الى اضافة الكبريت. 


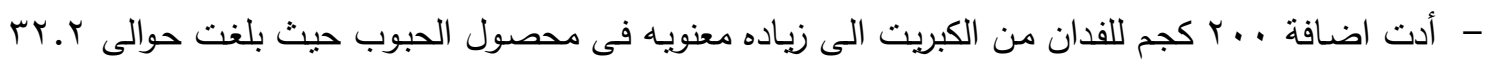

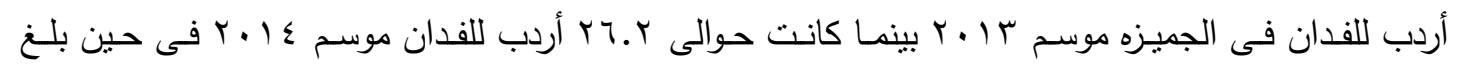

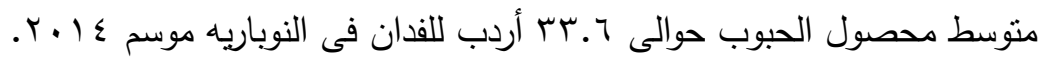

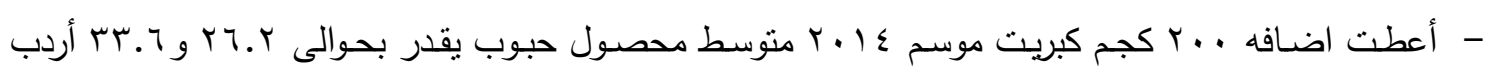
للفدان فى الجميزه والنوباريه على النوالى.

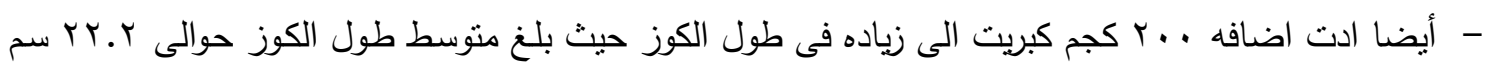

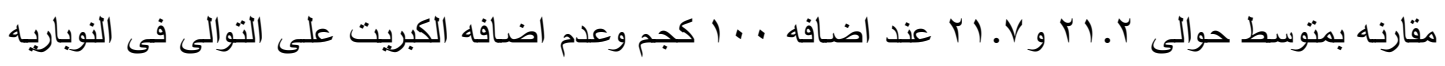
موسم ع I.r.

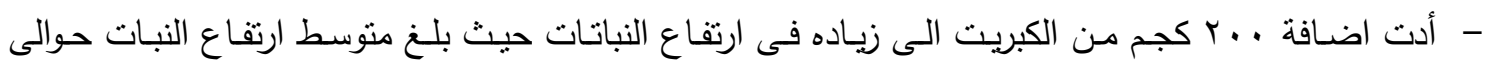

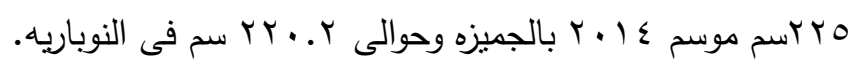

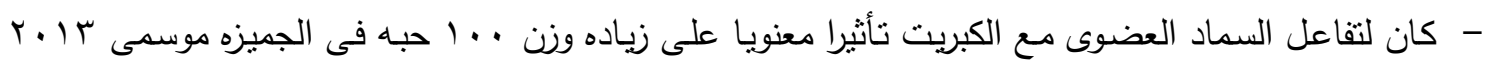

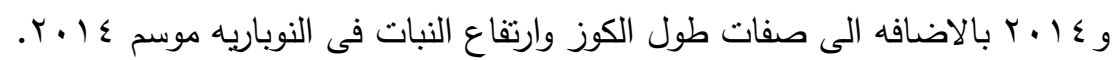

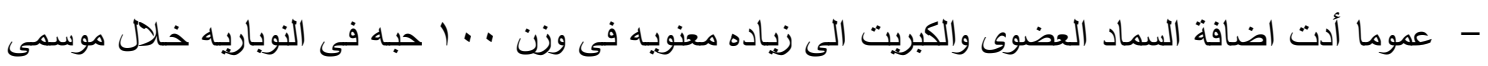

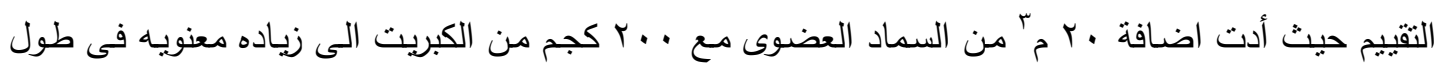
الكوز فى موقع النوباريه. 
